\title{
O coletivo Critical Art Ensemble e a estética do distúrbio
}

\author{
The Critical Art Ensemble and the aesthetics \\ of disturbance
}

El colectivo Critical Art Ensemble y la estética
de la perturbación

Recebido em 31-08-2020

Modificado em 01-10-2020

Aprovado para publicação em 03-11-2020

\section{Lucas Fortunato Rêgo de Medeiros}

Orcid: 0000-0002-5408-513X

Doutorado em Ciências Sociais pela Universidade Federal do Rio Grande do Norte - UFRN, Brasil. Professor do Departamento de Ciências Sociais da UFRN. Integrante do Grupo de Pesquisa Marginália. A Pesquisa de Doutorado, que resultou no artigo, foi financiada pela Coordenação de Aperfeiçoamento de Pessoal de Nível Superior - CAPES. E-mail: lucasfortitude@gmail.com

\section{Alexsandro Galeno Araújo Dantas}

Orcid: 0000-0001-5103-0339

Doutorado em Ciências Sociais pela Pontifícia Universidade Católica de São Paulo - PUC, Brasil. Pósdoutorado em Comunicação na Universidade de São Paulo. Professor nas Pós-Graduações de Ciências Sociais/PPGCS e de Estudos da Mídia/PPGEM da Universidade Federal do Rio Grande do Norte - UFRN. Membro do Grupo de Pesquisa Marginália. E-mail: alexgalenno@gmail.com

\section{Resumo}

O presente artigo tem por objetivo abordar o Critical Art Ensemble (CAE), um coletivo de artistas ativistas estadunidenses que, desde a década de 1990, promove criativas conexões entre arte, intervenção e teoria crítica. Com uma perspectiva micropolítica e suportes teóricos da sociologia, da história e da crítica da arte contemporânea, apresentamos o lugar do CAE no contexto socio-histórico que denominamos neocoletivismo, fenômeno sociológico emergente nas décadas recentes, e algumas de suas formas de expressão. Trata-se de um estudo de caso baseado em uma pesquisa bibliográfica e documental. Os dados analisados permitem compreender a trajetória do coletivo, sua forma de se organizar, criar e agir na esfera da cultura. Os resultados da pesquisa demonstram que o CAE é um caso exemplar do neocoletivismo, tendência caracterizada por formas de atuação intervencionistas em que estética e política tornam-se, por vezes, indiscerníveis em suas expressões semióticas e culturais.

Palavras-chaves: Critical art ensemble; plágio utópico; teatro recombinante; estética do distúrbio; neocoletivismo. 


\section{Introdução}

A arte pode agir como catalisador para o pensamento crítico e imaginativo, como um sinalizador de identidade política e solidariedade. Nenhum trabalho individual mudou o mundo. É a produção coletiva que importa.

Critical Art Ensemble ${ }^{1}$

Este artigo é resultado de uma pesquisa de doutorado realizada no período 2016-2019. Trata-se de um estudo de caso que envolve ciências sociais e história das artes. A pesquisa, amparada por uma vasta bibliografia pertinente ao tema, fez um levantamento documental da trajetória e das produções do Critical Art Ensemble (CAE), um coletivo estadunidense que atua na esfera pública com diversas formas de expressão artísticas e culturais.

Há pelo menos dois motivos que justificam o estudo desse coletivo, em especial, o reconhecimento de sua trajetória que se prolonga por mais de 30 anos inteiramente dedicados a promover novas formas de se fazer arte crítica, ciência e ativismo de forma coletiva. Uma avaliação lúcida de seu legado colocará o grupo em lugar de destaque na história da arte contemporânea. A criação de ferramentas conceituais e a elaboração de matrizes de ação do CAE estão entre as mais prolíficas no circuito da arte internacional recente. Mais do que um simples coletivo de artistas, o CAE se coloca em várias frentes de ação, até mesmo na produção de obras teóricas nas quais empreende um tratamento transdisciplinar aos problemas abordados. As tecnologias, por exemplo, são tematizadas pelo viés crítico, político e artístico, de forma teórica e engajada, com a mobilização de conteúdos científicos e filosóficos dos mais prestigiados na história do pensamento crítico contemporâneo. A bibliografia produzida pelo $\mathrm{CAE}$ conta com 8 livros e diversos artigos traduzidos para vários idiomas, somando-se a uma vasta produção de vídeos e de exposições, performances e intervenções dentro e fora de museus, em galerias, nas ruas, na internet, nas Américas, na Europa e na Ásia.

O segundo motivo tem a ver com a recepção do CAE no Brasil, que se deu muito cedo com a tradução do primeiro livro autoral do grupo, intitulado Distúrbio Eletrônico e lançado em 2001 pelo Coletivo Baderna em parceria com a Conrad Editora do Brasil. O livro circulou bem entre os ativistas do campo artístico cultural e deixou sua marca na história recente do neocoletivismo brasileiro. Ricardo Rosas (2003), pesquisador de mídia tática e ativismo contemporâneo, acompanhou de perto a emergência dos coletivos artísticos culturais no país e, em alguns dos seus artigos, considerados referências sobre o assunto, o CAE é mencionado como um dos expoentes de mídia tática para os ativistas brasileiros. Nos anos seguintes, o

\footnotetext{
${ }^{1}$ Citado por André Luiz Mesquita (2008:42).
} 
CAE começa a aparecer também em publicações acadêmicas (Xavier, 2006; Fortunato, Gonçalves Filho, Loreto, 2010), quando, finalmente, compõe objeto de pesquisas de pósgraduação. Para citar somente os trabalhos em que o CAE protagoniza um papel central, podemos mencionar: "Insurgências poéticas: arte ativista e ação coletiva (1990-2000)", dissertação de mestrado de André Mesquita (2008); “Teoria da arte hacker: estética, diferença e transgressão tecnológica", tese de doutorado de Daniel de Souza Neves Hora (2015); e mais recentemente, uma tese integralmente dedicada ao coletivo, intitulada "Critical Art Ensemble: a máquina de guerra e os arsenais antropotécnicos da revolta”, de Lucas Fortunato (2019).

Devido a sua trajetória de mais de 30 anos, há muitos registros das produções do CAE, em fotos e vídeos, em livros e na internet. A fim de se ter acesso à vasta e diversificada produção do coletivo, foram realizadas pesquisas bibliográficas em livros de autoria do grupo e sobre o CAE (teoria e história da arte contemporânea, críticas de arte, catálogos de exposições, entre outras fontes), bem como uma ampla pesquisa documental na internet, da qual resultou a catalogação das produções do coletivo e sobre ele (entrevistas, fotos, vídeos, artigos em diversos idiomas etc). Com base nesse levantamento histórico, imagético e discursivo, foi possível analisar as produções teóricas e práticas do coletivo, objetivo principal deste artigo.

A trajetória do CAE compreende exatamente o período de emergência do que denominamos neocoletivismo, fenômeno micropolítico característico dos movimentos póssocialistas (Lazzarato, 2006) que se munem da capacidade criativa da inteligência coletiva acoplada às tecnologias então disponíveis.

Como o próprio nome do grupo indica, o CAE pretende ser crítico do mundo atual, assim como dos usos e das apropriações das artes, das tecnologias e do conhecimento por parte das instituições, da economia e do Estado contemporâneos. Para tanto, o grupo se vale de performances, intervenções, instalações, vídeos, palestras e livros, sempre agenciados para dar visibilidade e fazer reverberar sua arte, seja no contato direto com o público, seja na dimensão virtual das ideias ou do ciberespaço. Por tudo isso, o CAE se destaca entre os coletivos de nosso tempo, justamente por praticar uma arte que é inteiramente política, crítica e atual.

O artigo aqui apresentado foi pensado como uma introdução geral ao CAE. Para situálo em relação à linha do tempo artística, de início será tratada a inserção do grupo na história das micropolíticas e sua recepção no Brasil. O enfoque a seguir será dado às principais características do grupo. Depois de uma apresentação geral, na qual se expõe o que o grupo é, como se organiza, o que faz e pensa, a melhor maneira de compreendê-lo é conhecer os 
métodos empregados nas suas elaborações teóricas e formas de expressão no campo artístico e cultural. Ao fim da leitura, espera-se que se tenha uma visão geral do CAE, suas matrizes de expressão praticadas no curso de sua trajetória e seu lugar no interior do neocoletivismo, que vem marcando as micropolíticas contemporâneas.

\section{Micropolítica e o neocoletivismo}

O tema dos coletivos artísticos culturais tem despertado cada vez mais interesse de pesquisadores e analistas sociais. Há uma explicação histórica e sociológica para isso. O argumento histórico começa com o fato de que, na história das artes modernas, o coletivismo tem sido uma constante. Alan Moore (2002) afirma que a existência de coletivos faz parte da história da arte desde ao menos o Renascimento e identifica nas vanguardas históricas, nos movimentos contraculturais e nos grupos artísticos e ativistas do século XX uma tendência de se organizar em coletivos. A inclinação ao coletivismo até os anos 2000 é enfatizada também por Blake Stimson e Gregory Sholette (2007), com um enfoque analítico e histórico a partir de 1945, período em que o coletivismo artístico cultural se tornará cada vez mais politizado. Em suma, a presença dos coletivos na esfera pública remonta a uma rica história desde ao menos o pós-guerra, período que foi marcado por uma efervescência micropolítica, para usar a expressão cara a Félix Guattari e empregada por Gilles Deleuze (2004).

No curso do século XX, a disposição ao coletivismo presente no campo artístico adentrou gradativamente a cultura com formas de atuar politicamente muito mais livres e criativas do que os meios empregados pelos movimentos sociais clássicos, herdeiros das causas operárias do século XIX. Na recomposição política e cultural do pós-guerra, essa característica finalmente se intensificou como tendência também nos movimentos sociais.

Em termos sociológicos, isso se explica pelo fato de que as mutações subjetivas resultantes da crescente complexidade social identificada nas metrópoles ocidentais extrapolaram a capacidade que os movimentos sociais classistas tinham de expressar politicamente o desejo coletivo. A multiplicidade do desejo e a correspondente diversidade cultural resultaram na invenção de formas de expressar as reivindicações dos protagonistas da vez, jovens, estudantes, minorias, feministas, homossexuais, ecologistas, movimentos antirracistas, anticoloniais, antipsiquiatria, entre outros. A saída encontrada para fazer valer a potência política do desejo foi a formação de vários coletivos, estes sim, capazes de canalizar e expressar as potências dos desejos minoritários.

Os protagonistas das novas reivindicações culturais e políticas vieram somar seus 
esforços e suas esperanças como vias alternativas aos partidos e sindicatos há muito consolidados como instâncias da luta de classes. Assim, ocuparam a arena pública movimentos minoritários, grupos de afinidade e as mais distintas agremiações com intenções políticas específicas. Neste fenômeno, Guattari (1977) viu a eclosão do desejo potencialmente revolucionário, que não cabe em fórmulas definitivas e, por isso, se exprime de distintas formas no campo social, cultural e político como uma potência mutante e transformadora.

Da década de 1990 em diante, ocorreu um fenômeno semelhante no campo das artes e das resistências culturais, de forma difusa e desigual em vários países, porém em âmbito mundial: a eclosão do desejo revolucionário, mais especificamente nos circuitos da arte ativista que se reinventava para contrapor uma alternativa à cooptação da potência artística para propósitos capitalistas, espetaculares, industriais e mercadológicos.

O impasse diante da apropriação espetacular das artes no contexto neoliberal obrigou a resistência cultural a desenvolver novas formas de atuação na esfera da cultura sem se submeter aos imperativos dominantes. A isso se deve a histórica tendência da arte crítica em recorrer a formas de intervenção pragmáticas, que caracteriza o período que vai dos anos 90 até hoje (Thompson, 2017). As artes coletivas, socialmente engajadas, e os coletivos que se organizaram em distintos países começaram a intervir em comunidades, em locais específicos, realizando um trabalho cultural de intervenção micropolítica que, mais tarde, somaria esforços com os movimentos pela alterglobalização.

$\mathrm{O}$ advento da internet desempenhou um papel fundamental na ativação do neocoletivismo da década de 1990 em diante, pois possibilitou ao campo cultural, artístico e micropolítico um crescimento considerável em termos de articulações, formas de organização, compartilhamento e novos repertórios de ação impulsionados pela estrutura tecnológica disponível.

No Brasil, o tema dos coletivos ressurge a partir de 2013 como objeto de análise e estudos, em parte, devido à visibilidade que os coletivos ganharam com o protagonismo político cultural na cena brasileira. Entretanto, o histórico dos coletivos no país na sua forma contemporânea remonta à virada da década de 1990 para os anos 2000. O histórico brasileiro de coletivos artísticos culturais tem mais tempo, ao menos desde a década de 1970. No entanto, Ricardo Rosas (2006) encontra na década de 1980 uma descontinuidade histórica desse tipo de organização cultural. Isso indica que os coletivos emergentes no final da década de 1990 possuem uma genealogia própria, diferente, portanto, da dos coletivos nacionais de outrora. Em outra pesquisa sobre arte ativista e ação coletiva, André Mesquita (2008:220) identifica no cenário latino-americano da década de 1990 a emergência de um "novo 
coletivismo artístico". Portanto, parece-nos importante situar a multiplicação de coletivos no Brasil pós-2013, no curso de uma tendência mais ampla que encontra sua proveniência genealógica no ativismo micropolítico dos anos 2000.

Nós defendemos que a emergência de coletivos na virada dos anos 2000 se dá em consonância com a movimentação em torno dos Dias de Ação Global dos Povos, que foi marcada pela Batalha de Seattle e envolveu movimentos de rua, internet, performances, mídia tática e intervencionismo. São esses elementos que confluem para a reconfiguração micropolítica do período em grupos de afinidade e coletivos ativistas não partidários de tendências libertárias (McKee, 2016:16), que operam segundo a lógica das multiplicidades, as mesmas características que irão se prolongar nos anos seguintes informando o neocoletivismo contemporâneo, identificado como fenômeno difuso e múltiplo em diversos países.

No Brasil, o Centro de Mídia Independente (CMI) e o Coletivo Baderna são exemplos históricos desse acontecimento social. O CMI foi criado no calor da Batalha de Seattle, em 1999, e desde então se articula como uma rede transnacional de produtores de informação independente. Por sua vez, o Coletivo Baderna, aproveitando a efervescência do momento, trouxe para o Brasil no início dos anos 2000 obras seminais para o ativismo contemporâneo, tais como: Situacionista: teoria e prática da revolução, TAZ: zona autônoma temporária, Urgência das Ruas e, por fim, Distúrbio Eletrônico, de autoria do Critical Art Ensemble, títulos que deixaram suas marcas na história dos coletivos da atualidade.

O CAE estava em plena atividade quando entrou no radar do ativismo brasileiro. Seu ativismo, porém, passou ao largo das movimentações que acompanhavam as reuniões dos órgãos internacionais do capitalismo. Na realidade, o grupo apostava pelo menos em duas frontes de atuação: no espaço cibernético, por meio do apoio e da promoção da resistência hacker e da desobediência civil eletrônica, e, em segundo lugar, no campo das práticas artísticas socialmente engajadas diretamente no meio cultural que o grupo materializava com o teatro recombinante.

\section{Critical Art Ensemble (CAE)}

O CAE foi criado há mais de três décadas por Steve Kurtz e Steven Barnes, que na época iniciavam suas respectivas carreiras profissionais e artísticas nos Estados Unidos (CAE, 2012:20). Para um coletivo que começou com duas pessoas produzindo vídeos conceituais de curta duração, é de surpreender a produção prolífica e numerosa do grupo durante sua trajetória. Atualmente, o portfólio do coletivo conta com a produção de curtas-metragens, 
performances, obras de mídia tática, intervenções micropolíticas, sites na internet, assim como exposições dentro e fora dos museus em diversos países.

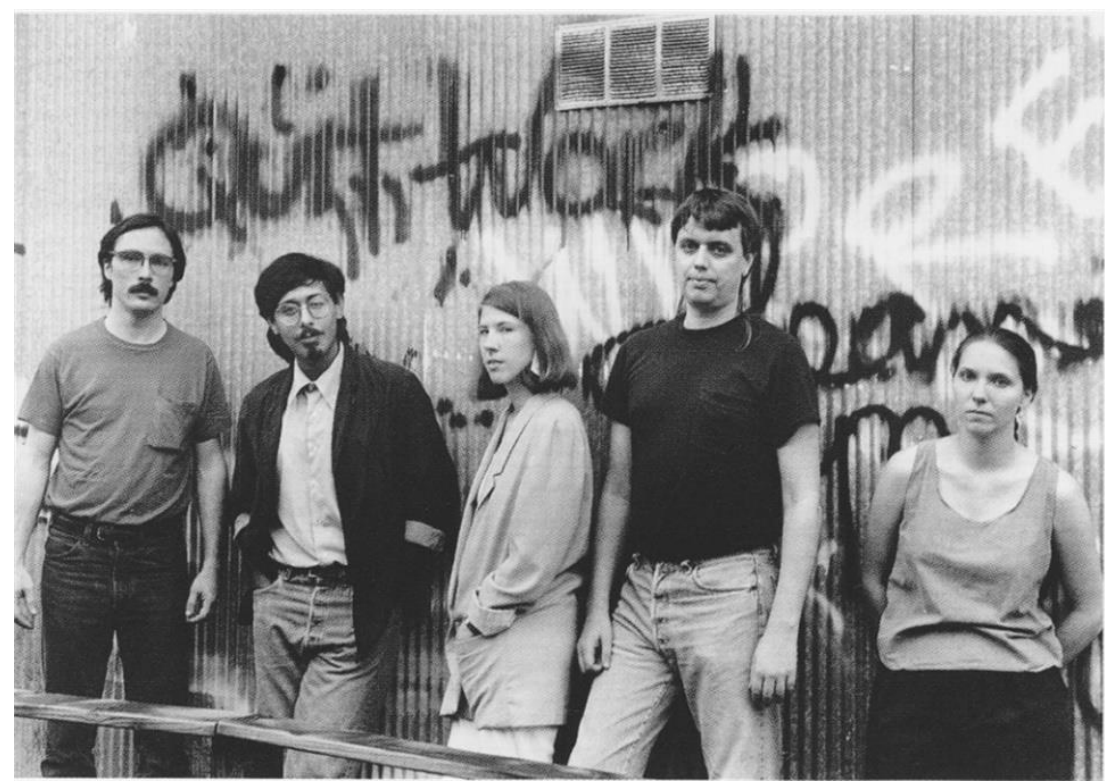

Imagem 1 - Critical Art Ensemble (1987). Da esquerda para a direita: Steven Barnes, Ricardo Dominguez, Hope Kurtz, Steve Kurtz e Dorian Burr (CAE, 2012:20).

Além dessa variedade de formas de expressão, o CAE também se mostra um coletivo versado na reflexão teórica-crítica e nas letras, como se pode comprovar com os escritos, ensaios e livros publicados pelo grupo no decorrer de sua carreira. Hoje a produção teórica do grupo soma ao todo oito livros, dentre os quais, sete estão inteiramente disponíveis para livre acesso na página do grupo ${ }^{2}$. Os temas abordados nas publicações são ricos em conteúdo e expressam um pensamento antenado com a atualidade nos campos das artes, da política, da tecnologia e dos movimentos sociais.

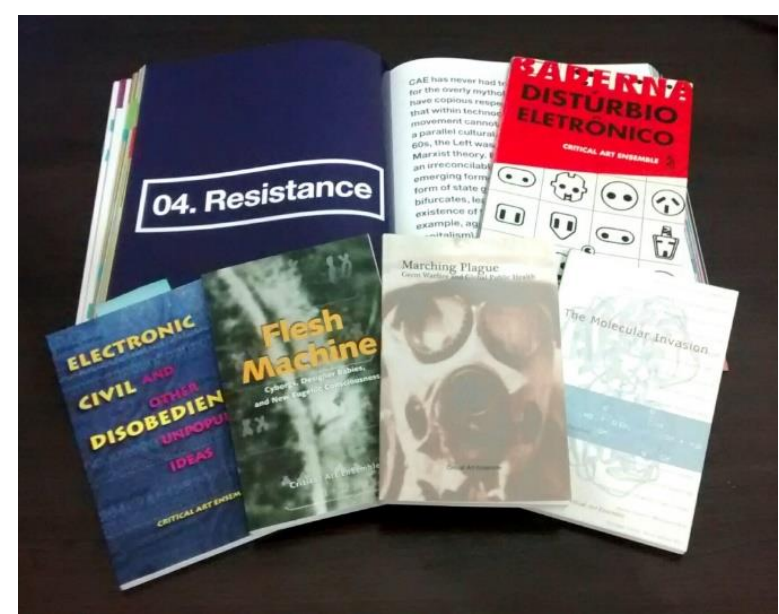

Imagem 2 - Livros do CAE (imagem dos autores)

\footnotetext{
${ }^{2}$ Cf. http://critical-art.net/
} 
Em uma época na qual o uso da internet como ferramenta de luta política e social era ainda um prospecto de ficção científica, os membros do CAE, de forma pioneira, lançaram-se na pesquisa e nos experimentos para a formação de uma resistência eletrônica, afinada com os mais recentes desenvolvimentos tecnológicos no campo da informática e da comunicação de massas. Posteriormente, acompanharam as inovações no campo da biotecnologia. A decodificação do genoma humano, a manipulação de DNAs e a fabricação de alimentos transgênicos também foram problematizados pelo pensamento crítico do grupo, que ousou com a arte da performance e do teatro recombinante (tratado em detalhes a seguir) levantar questões contemporâneas na esfera pública, sempre de forma inovadora na linha de frente da arte e da tecnologia.

O CAE tem por inspiração a arte guerrilha, o ciberfeminismo, o intervencionismo, a mídia tática e o ativismo cultural, práticas que vão na contramão da lógica global da busca por lucro, competição e consumo. Em vez disso, sempre se engajou em atividades orientadas pelos princípios de autonomia, cooperação e prazer.

Dentre as várias formas de expressão do ativismo cultural do grupo se destacam intervenções de mídia tática, performances, intervenções e distúrbios com o objetivo declarado de revelar, confrontar e subverter tendências autoritárias na esfera da cultura.

Durante sua trajetória, é possível identificar pelo menos três grandes linhas de força que nortearam as ações do grupo, cada uma caracterizada por uma abordagem de conjunto. A primeira marcou os anos iniciais, de 1986 até 1994 aproximadamente, o período da produção de vídeos e de eventos multimídia, no qual o CAE adquiriu ampla experiência com o ativismo artístico na esfera cultural e acumulou reflexões sobre o papel das tecnologias na resistência devido à produção de vídeos amadores quase sempre conceituais e uma série de eventos multimídias.

Em seguida, a produção do CAE foi marcada pela junção da teoria crítica com a práxis artística, norteada pela incorporação das tecnologias da informação e da comunicação às suas reflexões e performances, bem como ao ativismo do grupo. Nesse período, o CAE publicou de forma pioneira seus primeiros livros teóricos, que sintetizam os aspectos críticos e reflexivos de base para o ativismo e a resistência cultural praticada por seus integrantes.

Nos primeiros anos do ciberativismo, as obras do CAE The Electronic Disturbance (1994) e Electronic Civil Disobedience (1996) tiveram uma repercussão considerável. A primeira delas tornou-se uma espécie de best-seller underground entre os títulos não ficcionais e, por conta disso, logo foi traduzido para diversos idiomas. Na obra Digital Resistance: Explorations in Tactical Media (2001), informática, mídia tática, biotecnologia e 
robótica são investigadas na tentativa de se apontar os seus usos possíveis em prol de uma resistência eletrônica, a despeito dos imperativos do empreendedorismo e do lucro geralmente associados a tais tecnologias.

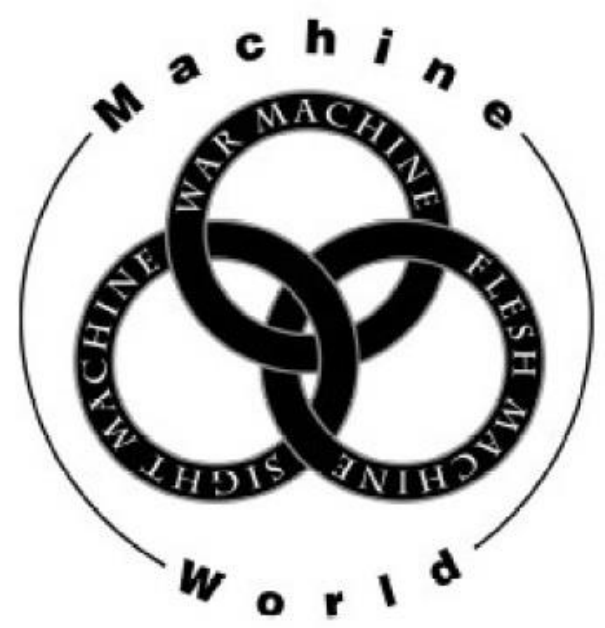

Imagem 3 - Machine World. Arte do CAE (1998:2)

Por fim, a terceira linha de força temática do grupo foi a das biotecnologias, que focou nas pesquisas científicas de clonagem e decodificação do genoma humano, nas questões acerca da manipulação do DNA, da reprodução artificial da vida, assim como dos alimentos transgênicos e de questões ecológicas e ambientais. As pesquisas sobre essas temáticas resultaram na publicação de quatro obras: Flesh Machine (1998), The Molecular Invasion (2002), Marching Plague (2006) e, por fim, o mais recente, Aesthetics, Necropolitics, and Environmental Struggle, publicado em 2018 depois de um hiato na produção teórica de mais de uma década.

Desta forma, o grupo tem abordado alguns dos maiores sistemas tecnopolíticos de nosso tempo: o complexo informático dos meios de comunicação e o complexo biotecnológico. Os livros que tratam dessas temáticas fazem dialogar outsiders da crítica radical com o cânone científico e filosófico do ocidente, especialmente o pensamento moderno e contemporâneo. Tendo por base esse escopo, emerge um pensamento que funda discursividades acerca da política e das tecnologias contemporâneas, com uma diferença em relação à produção acadêmica, por se tratar de um pensamento engajado nas lutas.

O CAE pode ser considerado, portanto, um coletivo de criação e estudos integrados na sua acepção mais complexa, ou seja, um coletivo que se esforça por empreender pesquisas teóricas, empíricas e práticas nas intersecções entre arte, teoria crítica, tecnologia e política radical. Com muita criatividade, o grupo une arte, ciência e filosofia em um agenciamento 
complexo no qual política e tecnologia desempenham papéis cruciais, tanto no pensamento como objeto de reflexão quanto na prática da resistência cultural.

Nessa espécie de máquina artística montada pelo coletivo, a arte é praticada como tática micropolítica, que se vale da ciência e da filosofia como recursos para nutrir o pensamento crítico, ao passo que a tecnologia, sempre presente, opera como meio de produção e propagação dos inventos teóricos e estéticos do grupo.

O resultado desse duplo processo de pesquisa e criação é nada menos que o prenúncio de uma espécie de Universidade Experimental e Nômade (Mirzoeff, 2004), que tenta seguir os fluxos e as tendências da sociedade global para melhor questionar os rumos da civilização, da cultura e das instituições conectadas por altas tecnologias.

$\mathrm{Na}$ prática de uma universidade experimental, os artistas intervêm em um campo particular de estudo (que pode ser urbanismo, informática, biotecnologia, antropologia ou ecologia, por exemplo) a fim de elaborar perspectivas críticas alternativas. Por vezes, as pesquisas conduzidas nos moldes de uma universidade experimental demonstram uma urgência que as alinham com um tipo de ativismo contemporâneo. Nela, a escolha do tema sempre se faz em função de um problema que emerge do presente, e a forma de colocá-lo, não raro, a vincula à dimensão política. Por isso, a universidade experimental pode ser responsável por colocar em questão, com soluções criativas e inovadoras, o problema político da produção especializada do conhecimento.

Assim, ao colocar em questão as estreitas relações da tecnologia com a ciência e o capitalismo, o CAE elabora um discurso político que expressa e produz outro tipo de sujeito, mais propenso a experimentar éticas e estéticas libertárias. Demonstra em suas obras, portanto, que o propósito da crítica não é simplesmente seguir as pistas deixadas por governos, corporações, agências dos mass media ou militares, como se a tarefa da resistência fosse viver à sombra do poder.

Com relação à organização e à dinâmica internas, o CAE decidiu assumir um modelo que comporta certa divisão de tarefas, muito embora modificável e meramente funcional no que se refere aos processos de criação:

[...] nos quais a pessoa com mais experiência em uma determinada área teria o poder de fazer julgamentos finais sobre um projeto ou um elemento específico de um projeto. Por exemplo, o designer teria a última palavra em questões de design. Isso mantém o processo de tomada de decisão eficiente, mas sem introduzir a variedade de alienações comuns na divisão industrial e pós-industrial do trabalho (CAE, 2012:20). 
A divisão das tarefas responde ao princípio de respeitar as individualidades e valorizar os talentos de cada integrante. Por isso também, o tamanho do coletivo se manteve pequeno, do tipo celular, e contou com o máximo de 7 integrantes em uma de suas formações, embora atualmente se mantenha com 3 membros (CAE, 2012:272).

O legado do CAE deixa entrever sua capacidade criativa em condensar problemáticas fundamentais da época presente, ao mesmo tempo em que demonstra o resultado de um incansável esforço em estabelecer as condições para que os experimentos artísticos ultrapassem quaisquer fronteiras estéticas, epistemológicas, políticas e tecnológicas para, enfim, atingirem a vida cotidiana.

\section{Matrizes e formas de expressão do CAE}

Como um coletivo de artistas ativistas, o CAE mobiliza uma série de meios teóricos e práticos para consolidar seu pensar e agir. Às diversas formas de expressão do grupo correspondem algumas matrizes executadas exemplarmente na elaboração de suas obras teóricas e práticas. É com base nelas que se materializa sua estética do distúrbio.

A primeira delas é o plágio utópico, que pode ser compreendido como uma espécie de colagem conceitual de ideias, imagens ou signos apropriados dos mais diversos contextos e inseridos em um novo agenciamento discursivo, imagético ou micropolítico. Sejam quais forem os elementos apropriados (que podem ser ideias, imagens, teorias, objetos, práticas etc.), o objetivo é produzir novos sentidos e significados com a recombinação artística deles.

A segunda matriz refere-se mais às performances e intervenções do grupo. Uma das principais formas do CAE atuar no campo das artes é por meio do teatro recombinante. Embora seja algo semelhante a uma performance, está mais para uma intervenção. O grupo inova, no entanto, ao colocar o elemento tecnológico como um componente fundamental na prática do teatro recombinante. Além do corpo do performer, é comum o uso de aparelhos e dispositivos maquínicos recombinados em uma matriz performativa que une diversos elementos em seu agenciamento, sejam componentes humanos ou tecnológicos, semióticos, imagéticos ou discursivos, apropriados para criar um acontecimento micropolítico.

Para tratar das matrizes e das formas de expressão do CAE, será apresentada inicialmente a matriz do plágio utópico. 


\section{Plágio utópico}

Geralmente, toda arte engajada com a sociedade, a cultura e principalmente o público, demanda uma leitura da realidade que é pelo menos parcialmente sociológica. O emprego de termos oriundos das ciências humanas tem sido uma prática comum nas artes micropolíticas do tempo presente. Além do mais, o teor da arte voltada para o contato com o público e interessada nos efeitos coletivos, sociais e culturais exige, por parte do próprio artista, a elaboração de discursos e terminologias que remetem ao universo teórico das ciências sociais, e por isso as linguagens assim elaboradas são frequentemente carregadas de significado político.

O CAE assumiu esta tendência claramente ao construir um campo teórico no qual agencia um diálogo entre arte, ciência, filosofia e tecnologia. Nesse sentido, o aspecto teórico do grupo chama atenção pela criatividade conceitual. Tal inventividade nutre-se de muitas formas da filosofia, da ciência, da literatura e das artes. Não raro, o grupo se apropria de noções extraídas da história das ideias por uma espécie de afinidade eletiva para então compor o seu próprio pensamento conceitual. Atitude que remete à história da arte conceitual, porém com um novo viés, desta vez mais filosófico e imediatamente político do que focado na crítica às instituições artísticas. Em seu estudo sobre o tema, Paul Wood (2002:28-37) afirma:

\footnotetext{
A arte conceitual cresceu num espaço criado pela vanguarda, e o utilizou para estruturar uma crítica aos pressupostos do modernismo artístico, em particular ao seu foco exclusivamente dirigido ao estético e às reivindicações de autonomia da arte. (...) A atitude de certa forma relaxada da contracultura mais ampla, a sua característica ligeiramente nômade, assim como a postura universal de resistência ao brilho e ao consumo, pairavam sobre muitas das manifestações conceituais.
}

As concepções do CAE prolongam essas tendências direcionando-as ao emprego nas lutas micropolíticas no âmbito mais vasto da cultura e não somente ao campo artístico. As apropriações não pretendem captar uma ideia ou um conceito para tão somente reproduzi-lo. Para além de uma postura tipicamente acadêmica de apresentar e reproduzir conceitos elaborados por terceiros, como também para além da técnica do decalque, o grupo se apropria de noções, signos e conceitos existentes como operadores cognitivos que são remodelados pelo pensamento e adquirem outros sentidos em função de novos problemas. São os problemas colocados pelo coletivo que indicam os conceitos necessários e as formas de apropriação criativa.

Os sentidos e significados das palavras e das imagens são, assim, submetidos a torções e deformações pela operação artística que, a um só tempo, provoca uma mutação e uma 
recombinação (de signos, significantes e significados) capazes, portanto, de estimular a produção de subjetividades. Exemplos disso são os conceitos de pancapitalismo, poder nômade e mesmo plágio utópico, ambos construídos pela colagem e pela recombinação de conceitos e ideias pré-existentes, e que passam a compor um conteúdo modificado por serem remetidos a uma realidade distinta da que lhe deu origem a princípio.

O objetivo dessa espécie de plagiarismo não é citar, comentar, inserir notas ou referências, como seria de se esperar, senão experimentar uma livre desapropriação dos mais variados elementos encontrados na cultura pop ou na alta cultura com o propósito de atualizar o alvo do plágio utópico em novos contextos e fazê-lo ressoar algo diferente em relação ao que já se produziu até então. Nesse registro, a palavra utopia adquire um sentido semelhante à virtualidade, real, porém ainda não atual. Isso se dá, sobretudo, com as teorias, sejam artísticas, científicas ou filosóficas, que adentram no escopo do CAE em função de problemas concretos, reportadas, portanto, a situações sociais que exigem uma reflexão profunda para melhor compreendê-las. Nas palavras do CAE (2001a:89): "É aqui que o plágio progride além do niilismo. Ele não injeta somente ceticismo para ajudar a destruir sistemas totalitários que paralisam a invenção: ele participa da invenção, e dessa forma também é produtivo”.

Esta prática de apropriação artística de ideias, conceitos, noções e teorias é denominada de plágio utópico, porém se assemelha com um tipo de atitude incorporada pelas vanguardas artísticas desde o Dadaísmo, passando pela noção de détournement da Internacional Letrista e dos Situacionistas, chegando até o tempo presente transformada com a pop art:

\footnotetext{
Readymades, colagens, found art ou found text, intertextos, combines, détournement e apropriação - todos representam incursões no plágio. De fato, esses termos não são sinônimos perfeitos, mas todos cruzam uma série de significados básicos à filosofia e à atividade de plagiar (CAE, 2001a:85).
}

No entanto, a operação do plágio utópico, tal como é praticada pelo CAE, é mais artística do que a mera colagem e, muitas vezes, mais filosófica do que publicitária, pois supõe uma atividade intelectual crítica, intuitiva e construtivista no campo do pensamento conceitual propriamente dito.

$\mathrm{Na}$ década de 1960, os situacionistas designaram détournement o método de desapropriar as ideias, os signos, as teorias e os conceitos de forma subversiva para incorporálos em um contexto diferenciado. O método consiste em provocar um desvio, um deslocamento para um novo arranjo que resulta em uma torção no significado original, com o que o objeto do détournement adquire nova vida e uma potência revigorada canalizada para 
propósitos de resistência.

"O plágio é necessário", afirma Lautréamont ${ }^{3}$. Os situacionistas, que o trouxeram de volta à cena cultural no pós-guerra, respondem: "O que queremos, de fato, é que as ideias voltem a ser perigosas" (Internacional Situacionista, 2002:72). O uso emancipatório da linguagem passa pelo uso crítico, político e engajado das palavras, dos sentidos, das significações. Por isso, o détournement é o contrário da citação, que supõe reverência à autoridade teórica. Mais fundamentalmente, "o desvio é a linguagem fluida da antiideologia" e se coloca como um recurso ao alcance de todos para efetuar a crítica ao presente (Debord, 1997:134).

O desvio atualiza uma violência ou crueldade que está na base da ação criadora e, por isso, "incomoda e arrasta toda ordem existente" (Debord, 1997:134). No entanto, o desvio é subversivo somente para a ideologia burguesa, que se beneficia da ideia romantizada de autor como gênio. A genialidade metafísica é um embuste e uma barreira fácil de ser transposta quando a urgência da transformação social é o que importa. Contra a recuperação capitalista do ideal romântico do autor enquanto gerador de lucro, os situacionistas questionaram com a prática do desvio sua inutilidade para fins revolucionários.

O desvio é um método revolucionário que manifesta por meio da linguagem uma potência do pensamento e uma afirmação existencial engajada no presente. A tática do desvio restitui ao sujeito certa ousadia micropolítica, uma inocência poética que o impulsiona ao experimentalismo expressivo, seja na linguagem, na teoria, seja nas artes visuais, no cinema. É, portanto, um método ágil de passar uma mensagem, de subverter uma estrutura significante, pois estimula uma atitude ativa que trai o pacto velado da sociedade espetacular de se manter passivo, enquanto espectador, diante da privatização das ideias, das imagens, dos textos - interdição primeira e última da poesia.

O desvio situacionista tinha por função contribuir para a revolução da vida cotidiana e, assim, adquiria o sentido revolucionário da expropriação da cultura burguesa, do uso restrito da linguagem e da expressividade codificada pelos parâmetros da propriedade intelectual, da genialidade, do artista sagrado pelo campo mercadológico.

O conceito de plágio utópico, no CAE, é por si só um desvio, uma atualização do détournement situacionista, pois consubstancia uma desobediência poética enquanto revolta micropolítica contra o estatuto de autoridade que se atribui à linguagem, à imagem e às obras culturais em geral. Os situacionistas empregavam o desvio a favor da criação e do estímulo à

\footnotetext{
3 Citado por Michel Schneider (1990), Ladrões de palavras: ensaio sobre o plágio, a psicanálise e o pensamento. Campinas, Editora da Unicamp, p. 146.
} 
construção de situações, momentos vividos diretamente. O CAE insere o plágio utópico como tática para a recombinação da cultura em sentido amplo e multidimensional: a recombinação de discursos, teorias e imagens que ocorre no interior de recombinações performáticas e tecnológicas. Nesse sentido, détournement e plágio utópico nada mais são do que formas de experimentalismo expressivo, crítico e subversivo, colocados à disposição da resistência em suas mais diversas frontes. A diferença com relação aos situacionistas é que o CAE atua em uma época caracterizada pela emergência da cultura eletrônica, ainda mais propensa às recombinações, que são facilitadas pelas tecnologias comunicacionais informáticas.

Será que no desvio situacionista revela-se a expressão e a operatividade de uma potência destituinte? Debord concebe o método do dépaysement como duplo movimento de détournement ("desvio") e de renversement ("desarranjamento", "reviravolta"), colocação no "reverso" das produções da cultura moderna. Détournement e renversement são operados segundo uma compreensão crítica das condições e contradições presentes na sociedade (Aquino, 2006:173). A recombinação perseguida pelo plágio utópico do CAE nada mais é do que o desvio e a reversão da linguagem, das imagens, dos sentidos, das significâncias e da cultura em seu campo máximo de intervenção.

Com base nessa prática, encontram-se no léxico usado pelo CAE noções pouco usuais como pancapitalismo, poder nômade, máquina de visão, matriz performativa, teatro recombinante, entre outras, que compõem um vocabulário rico e exótico agenciado para descrever ora os elementos da resistência cultural, ora a sociedade contemporânea.

Com o plágio utópico, vê-se a retomada do valor de uso do conhecimento no momento de sua transformação em mercadoria global. Ante a tendência de transformar as ideias em propriedade privada, as resistências da atualidade expropriam as linguagens, os significados e o conhecimento em geral, seguindo a tendência do compartilhamento de informações e arquivos na rede internacional de computadores. Pirataria contracultural nos mares da modernidade líquida ${ }^{4}$. Ou como diz o CAE (2001a:88):

\footnotetext{
${ }^{4}$ Em um artigo sobre as mudanças recentes nas relações entre tecnologia, poder e civilização, há uma explicação sobre o termo "modernidade líquida" proposta pela sociólogo Zygmunt Bauman em suas análises: "Ao contrário das formações modernas que se constituíram de maneira sólida, as sociedades líquidas são definidas pela inconstância de suas estruturas, formas e instituições, que paradoxalmente se desfazem mais rápido do que se estruturam. Ao invés de perdurar no tempo, as instituições e estruturas da atualidade são tomadas em processos mais amplos remetidos à produção capitalista que exigem forçosamente mudanças, adaptações e reformulações de toda sorte, sempre em conformidade com as exigências econômicas e mercadológicas em âmbito transnacional ou planetário. A ideia da liquidez de que fala o sociólogo, nesse sentido, é usada para destacar o estado maleável, inconstante, dinâmico, adaptativo e mórfico do mundo social na sua versão contemporânea" (Fortunato; Galeno, 2018:99)
} 
É uma questão de reunir várias técnicas recortadas a fim de responder à onipresença dos transmissores que nos alimentam com seus discursos obsoletos (meios de comunicação de massa, publicidade, etc.). É uma questão de desacorrentar os códigos - não mais o sujeito - tal que alguma coisa arrebente, escape: palavras por trás de palavras, obsessões pessoais. Nasce outro tipo de palavra, que escapa do totalitarismo da mídia, mas que retém seu poder, e o volta contra seus velhos mestres.

Assim, o chamado plágio estético opera entre a possibilidade dada pela autonomia do pensamento e da criatividade, de um lado, e a urgência das tarefas que o agente cultural se coloca ante a época, de outro, o que exige respostas rápidas e de impacto aos desafios do tempo presente. Dessa forma, o CAE coloca em ação velhas ideias recolhidas do inesgotável arquivo da história com uma nova abordagem de método adaptada aos tempos atuais.

Além do plagiarismo aplicado ao universo teórico e imagético elaborado pelo CAE, existe a forma de expressão prática denominada teatro recombinante, uma espécie de matriz performática elaborada para a ação do grupo. Por meio de uma fusão do teatro com a performance, o CAE conecta os corpos, os signos e as tecnologias para criar um acontecimento micropolítico nas fronteiras da arte e da vida cotidiana. A forma de expressão práxica que compõe o teatro da resistência contemporânea agora tem seu lugar.

\section{O teatro recombinante}

O CAE sempre vislumbrou uma gama de atividades artísticas com potencial para compor a resistência e, por isso, se permitiu explorar livremente formas de pensar, fazer e praticar a arte. O plágio utópico sintetiza algumas contribuições extraídas exemplarmente da história da arte moderna, pois se nutre da colagem dadaísta, do détournement situacionista e da arte conceitual. Além desta tática estética e política, segue-se o teatro recombinante, mais direcionado à práxis artística levada ao limiar da performance e da vida cotidiana.

O teatro praticado pelo CAE é, portanto, uma espécie de performance com teor intervencionista. Tal concepção de teatro coloca em prática uma arte com características que remetem à performance e aos happenings. Diferente do teatro tradicional, que se orienta por uma narrativa, com personagens, tramas e clímax, no qual tudo aparentemente se resolve, a performance lida com o espaço e o tempo de forma fragmentária, situacionista e efêmera. Por isso prescinde praticamente de tudo o que constitui o teatro clássico, inclusive de palco. Não que seja uma restrição. Os elementos do teatro podem compor uma performance, mas tudo se torna opcional, pois o que importa é, antes de tudo, o corpo do performer e os efeitos de suas ações em uma dada realidade social. 
$\mathrm{Na}$ história da arte contemporânea, a performance ocupa um lugar privilegiado, pois parece expressar melhor o mundo fragmentado da modernidade líquida do que as encenações tradicionais orientadas por uma narrativa. Em uma performance, segundo uma definição histórica consagrada, o artista não precisa de um papel para interpretar, e muito menos de uma sequência de cenas encadeadas por uma linha narrativa. Mais do que isso, o performer não precisa sequer ser ator para incorporar uma série de movimentos, ações e falas. Uma pessoa comum pode muito bem performar sem remeter-se a um eu artista. Em termos corporais, então, a liberdade atinge seu nível máximo na performance. Do mesmo modo, geralmente não há espaço cênico específico para realizá-la. Pode ocorrer em qualquer lugar. Na medida em que a performance constrói um acontecimento estético, dirige-se igualmente a um coletivo de sujeitos que podem ou não participar diretamente do desenrolar da ação.

Nessa linha, como um desdobramento da arte performática, surgiu o “intervencionismo", ainda mais irruptivo, pois tem um caráter essencialmente penetrante no que se refere à coletividade e à dinâmica da vida cotidiana. Em termos genéricos, algumas práticas intervencionistas podem ser identificadas nas vanguardas históricas da arte moderna. Porém, o intervencionismo contemporâneo, ao menos nos Estados Unidos, remonta à virada da década dos anos 1990. Nato Thompson, curador de arte contemporânea, fez um levantamento de alguns coletivos intervencionistas e organizou uma exposição, em 2004, com alguns expoentes dessa vertente cultural, entre os quais figura o CAE. No livro que registra a pesquisa e a exposição, Thompson (2004:13) tece considerações importantes sobre o fenômeno. $\mathrm{Na}$ sua perspectiva, o termo "tática" é central para discutir práticas intervencionistas. Tática refere-se a procedimentos que se efetuam deliberadamente no interior da vida cotidiana como em um jogo. Os projetos intervencionistas são planejados e executados para "operar dentro e sob sistemas de poder e comércio usando as técnicas da arte".

Por tudo isso, muitas performances intervencionistas levam a arte às fronteiras da vida cotidiana, produzindo, assim, um acontecimento único e irrepetível, cujas repercussões são muitas vezes imprevisíveis. É o que faz o CAE vez por outra. Um exemplo apresentado pelo próprio coletivo ajuda a ilustrar o modo intervencionista de atuar. 


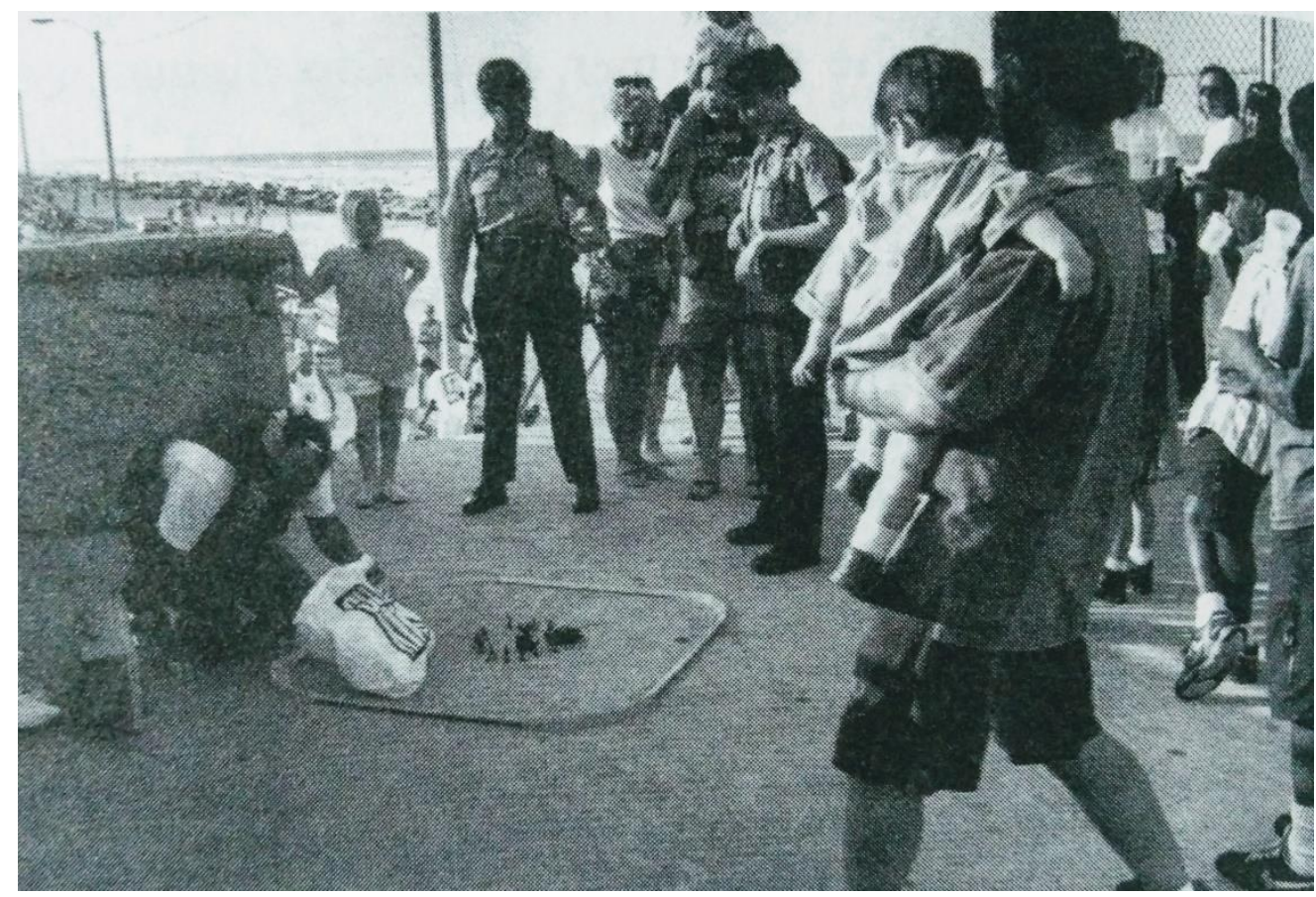

Imagem 4 - Exemplo de uma intervenção nômade na vida cotidiana (CAE, 1996:54)

Em um ponto turístico bem movimentado, uma pessoa munida de alguns pequenos brinquedos, como carrinhos em miniatura e umas pistas de plásticos montáveis, ocupa um lugar próximo a uma entrada ou saída de pessoas, onde o público circula. Em seguida, o performer senta-se e começa a brincar com os carrinhos, oferecendo um brinquedo para quem se mostrar interessado em participar. Enquanto isso, outros integrantes do grupo podem se insinuar no jogo sem se identificar como participantes. O que acontecerá não é possível antecipar por completo. Porém, como se trata de um local turístico, qualquer alteração na dinâmica pode chamar atenção das autoridades locais. Passados alguns minutos, as pessoas se aproximam, questionam-se acerca da atitude incompreensível, outras podem interagir, perguntar algo, ou mesmo brincar com a situação. Até que, momentos depois, seguranças ou policiais da área se aproximam para saber do que se trata. É quando a situação começa a se tornar mais intensa, pois o simples ato de brincar em uma passagem pública pode despertar atitudes autoritárias. Talvez os seguranças solicitem ao performer se retirar do local alegando algum motivo. Apesar das ordens, o performer ignora tudo à sua volta e continua brincando e, assim, chega-se ao momento de tensão, quando as pessoas no entorno podem falar, intervir, concordar, discordar. Instaura-se uma zona molecular na qual o resultado das ações torna-se imprevisível: as opiniões das pessoas afloram em palavras, gestos, e, em alguns casos, pode acontecer inclusive do performer ser detido fisicamente, com ou sem truculência. Por questões de segurança, é preciso identificar o momento de cessar a intervenção, antes que se 
chegue às vias de fato, e as pessoas envolvidas, entre si e com os seguranças, agridam-se fisicamente.

O importante em uma intervenção como essa é promover uma situação extracotidiana, como forma de instaurar em espaço público um debate sobre o autoritarismo, a ineficácia das leis ou a realidade do poder. As conclusões a que se pode chegar são muitas e variadas, por exemplo: brincar em determinados lugares pode despertar o despeito, a ira e a simpatia, suscitar as autoridades e até mesmo o abuso de poder. A liberdade civil não é sempre assegurada por aqueles que deveriam promover as condições para seu exercício. Uma intervenção nômade e simples semelhante a esta pode ser realizada por qualquer pessoa em praticamente toda cidade turística como forma de estimular diálogos e reflexões críticas (CAE, 1996:52-54).

$\mathrm{Na}$ prática do $\mathrm{CAE}$, o teatro da vida cotidiana adquire outro estatuto quando incorpora as tecnologias da informação e comunicação, com seus aparelhos e usos demonstráveis rearranjados em cena. Eis o seu teatro recombinante, que atualiza a arte da performance em um teatro intervencionista. Com uma diferença importante, pois inova no uso deliberado que faz de equipamentos eletrônicos nas cenas performáticas.

Sinteticamente, o teatro recombinante consiste em ambientes performáticos entrelaçados por meio dos quais os participantes podem fluir (CAE, 2001b:87). Teatro invisível, teatro de rua, teatro da vida cotidiana, entre outras possibilidades, podem ser turbinados com tecnologias de vários tipos, e o experimento então ganha um novo sentido.

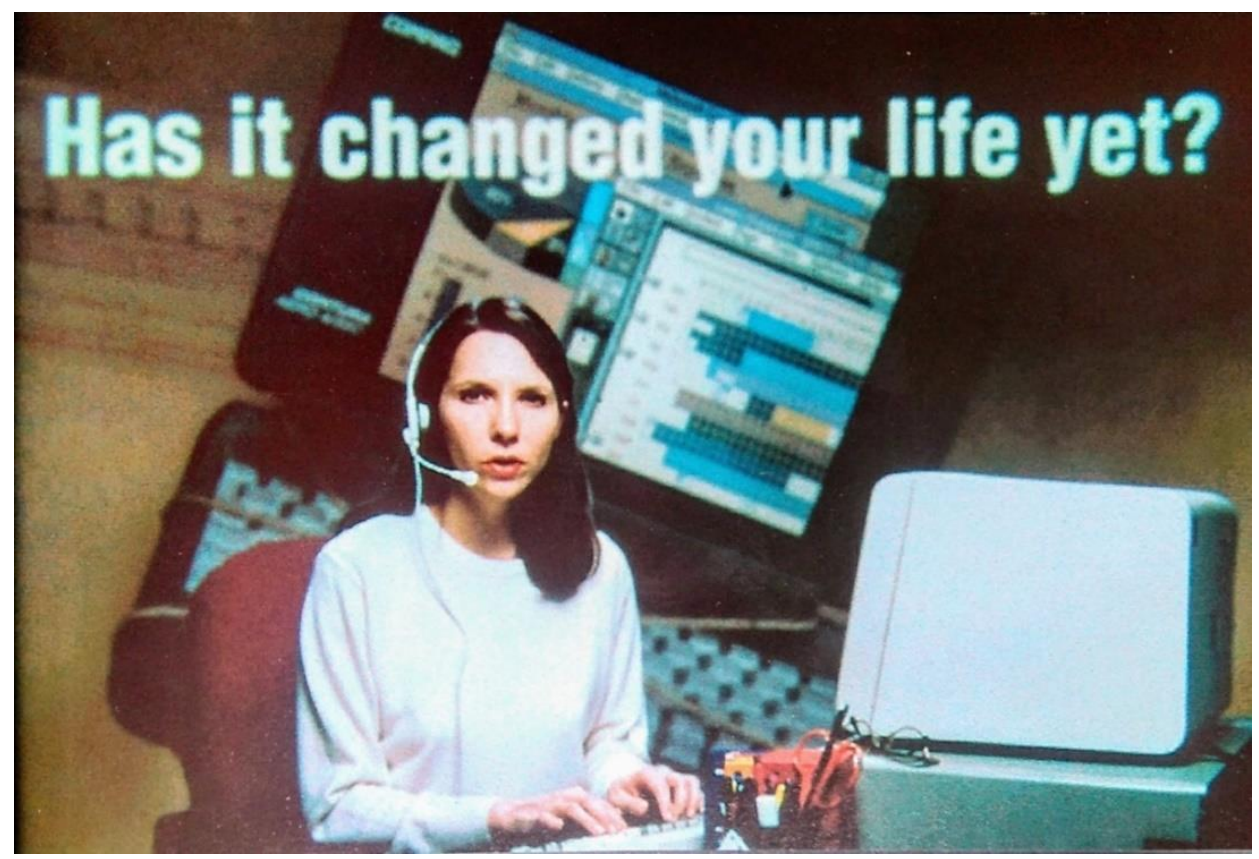

Imagem 5 - Dorian Burr performando uma cena do Teatro Recombinante (CAE, 2012:51) 
Na matriz performativa do grupo, a tecnologia compõe um elemento crucial, porém, ao mesmo tempo em que os aparelhos e as tecnologias são apropriados pelo agenciamento, seu sentido, quando remetido ao conjunto conceitual de base, adquire um caráter crítico. $\mathrm{O}$ principal objetivo é claro: "O novo teatro deveria dizer ao espectador como resistir à autoridade, independentemente da sua identidade política" (2001a:69). O CAE (2001a:65-66) o ilustra com um breve exemplo:

\begin{abstract}
Considere o seguinte cenário: um hacker está no palco com um computador e um modem. Trabalhando sem limite de tempo, o hacker invade bancos de dados, acessa seus arquivos e parte para apagá-los ou manipulá-los de acordo com seus próprios desejos. A performance termina quando o computador é desligado. Essa performance, embora tão simplificada, exprime a essência do distúrbio eletrônico. Uma ação como essa percorre em espiral a rede performativa, interligando de maneira nômade o teatro da vida quotidiana, o teatro tradicional e o teatro virtual. Representações múltiplas do artista participam explicitamente desse cenário para criar uma nova hierarquia de representação.
\end{abstract}

Com uma simples performance como essa é possível trazer ao debate uma série de questões. Como os dados eletrônicos de um indivíduo podem ser manipulados, distorcidos ou eliminados - ao dispor de um estranho - e, depois disso, repercutir seus efeitos na vida cotidiana, a despeito de leis. É possível discutir de uma perspectiva mais ampla, simulando, por exemplo, a invasão de um sistema de armazenamento de dados que acumula informações privadas de milhões de pessoas, mas que são agenciadas por corporações a fim de se obter lucros sem a devida autorização. Em uma cena de teatro recombinante dá para simular uma operação de disparos de e-mails tipo spams em grande quantidade, aleatoriamente, com vírus, worms ou fake news. Ou, ainda, demonstrar como é relativamente fácil alterar dados e fotos digitais com o simples uso de programas de computador de modo a falsear um registro, e associar isso a um crime ou a uma situação completamente diversa.

O CAE trabalhou com esse tipo de teatro durante anos em suas apresentações multimídias. As possibilidades são infinitas e podem ser aproveitadas para muitos propósitos de resistência. Existe até mesmo um potencial pedagógico de performances recombinantes como as esboçadas aqui rapidamente. Embora a sociedade tenha incorporado altas tecnologias, poucas pessoas têm real noção do que é possível fazer com elas quando se tem o domínio de ferramentas somente acessíveis a especialistas ou amadores com noções técnicas minimamente proficientes. Demonstrações criativas de algumas dessas habilidades, reais ou simuladas, por técnicos ou performers, e de seus efeitos na vida das pessoas na esfera pública, proporcionam grande potencial elucidativo, questionador e crítico. O debate daí advindo é um dos efeitos esperados do teatro recombinante. 
O CAE denomina a prática de tais performances de teatro recombinante justamente porque os elementos humanos e não humanos, linguísticos e discursivos, bem como semióticos, sígnicos e imagéticos, espaciais e tecnológicos, são combinados ao espaço cênico e virtual. A ideia é construir uma situação na qual a arte crítica tenha as condições de produzir seus efeitos sensíveis, estéticos e de pensamento no público. Recombinante também nos seus efeitos, ao repercutir nas subjetividades e na dinâmica da vida cotidiana, contribuindo, assim, para possíveis reconfigurações ideacionais, perceptivas ou mesmo micropolíticas.

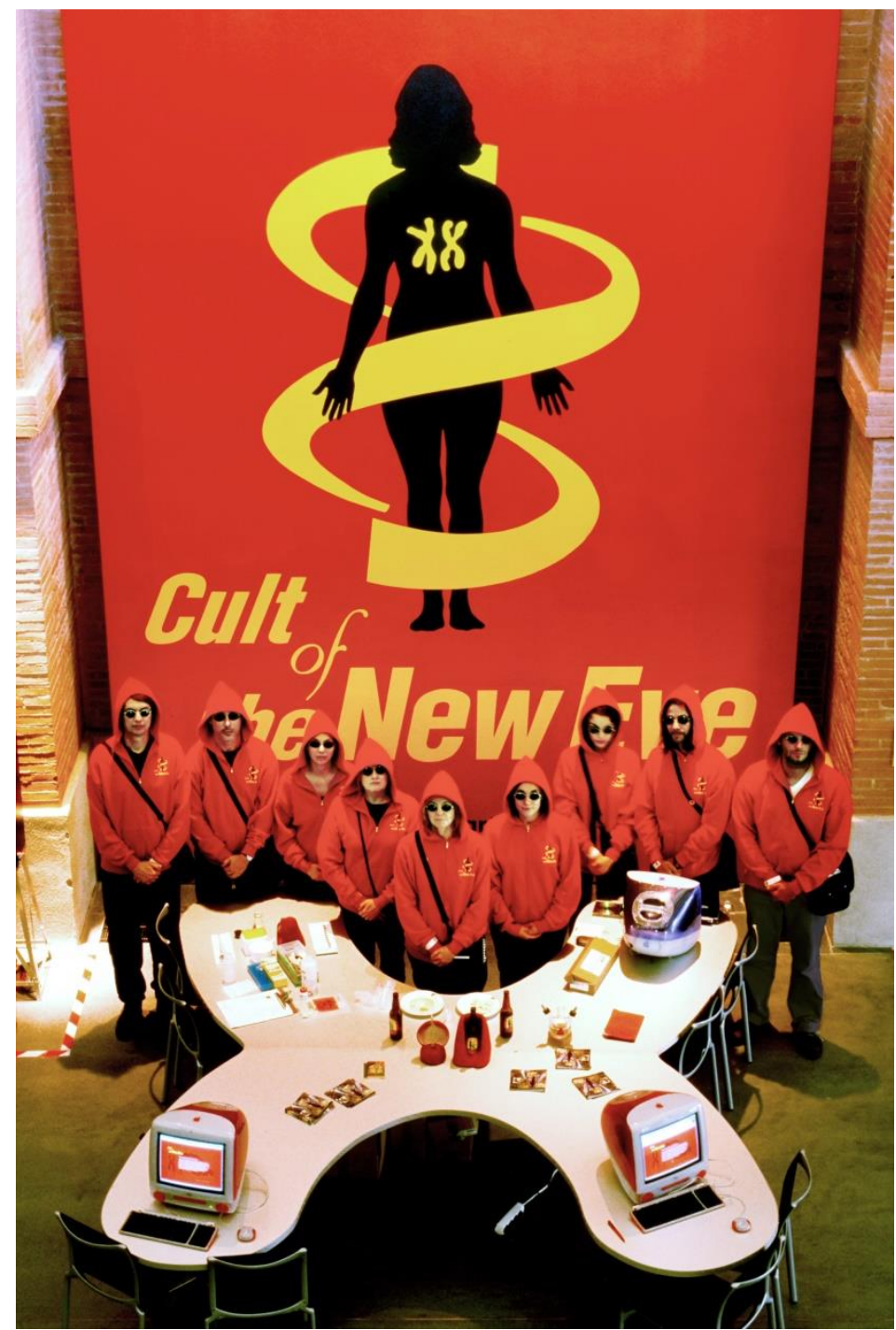

Imagem 6 - CAE, Teatro Recombinante, Cult of the New Eve, 2000 (CAE, 2012:266).

Esse teatro foi pensado para explorar a realidade com o mesmo ímpeto do hacker em face de um sistema informático. Na perspectiva do CAE, a prática hacker é a melhor maneira de desestabilizar a realidade e a estrutura prática de todos os teatros. Pekka Himanen (2001:8) chama a atenção para a abertura semântica do termo: 
Os próprios hackers sempre admitiram essa aplicação maior de sua atuação. Seu arquivo de jargões chama a atenção sobretudo para o fato de que um hacker é, fundamentalmente, 'um perito ou um entusiasta de qualquer área. É possível ser um hacker em astronomia, por exemplo'. Nesse sentido, é possível ser hacker sem ter nada a ver com computadores.

O teatro recombinante, portanto, submete as tecnologias eletrônicas e virtuais a um tratamento hacker para levar ao público algum grau de questionamento acerca do que essas mesmas tecnologias desempenham na esfera social, política, econômica e cultural. Assim, as matrizes da performance, do teatro eletrônico e da vida cotidiana se combinam para tornar patente os aspectos autoritários das tecnologias. Ora para desafiar os códigos e normatividades, ora para demonstrar os usos possíveis das tecnologias para os propósitos da resistência.

Ante as infinidades de matrizes interpretativas moldadas pelo espetáculo, todas investidas do caráter de verdade, cabe à estética do distúrbio minar o império das opiniões que obstruem a construção da autonomia nas suas dimensões individuais e coletivas. A provocação, a confusão e o distúrbio são meios de que se vale o teatro da resistência para desmontar as máquinas ideológicas e revelar potenciais escolhas não previstas pela grade interpretativa dominante do espetáculo (CAE, 2001a:69).

Tanto no caso do plágio utópico quanto na teoria prática do teatro recombinante notase um teor crítico e político latente, afinal, era de se esperar que um coletivo de arte crítica elevasse a estética ao patamar da contestação.

\section{A estética do distúrbio}

$\mathrm{Na}$ sociedade do espetáculo, realmente, não se pode esperar que os Estados ou os mercados promovam mudanças comportamentais, éticas e existenciais contrárias a seus pressupostos de controle, disciplina e consumo. Justo para fazer frente às tendências dominantes é que se formam as frentes da resistência cultural, nas quais os artistas e ativistas desempenham suas funções de revolucionários da vida cotidiana. Assim, a arte engajada, estimulada pelo ímpeto criador da revolta, pode contribuir com a tarefa de injetar novo ânimo na cultura.

O CAE desenvolveu sua própria maneira de praticar a resistência. Há duas formas de atuação que se complementam no amplo espectro de ação do grupo. A primeira, direcionada à teoria crítica, funda discursividades com a arte conceitual e o plágio utópico. Trata-se de uma forma de expressão de tipo racional, que articula discursos a fim de problematizar temáticas 
contemporâneas.

Somada a esta forma de intervenção na esfera epistemológica, existe a matriz performática do teatro recombinante, que une diversos registros performáticos, tais como teatro da vida cotidiana, teatro de rua e teatro eletrônico. Por meio de performances, instalações, contraespetáculos e intervenções, as formas de expressão do grupo ultrapassam os limites da racionalidade e do senso comum com técnicas lúdicas, desviantes e mesmo improvisadas capazes de afetar a imaginação e os sentidos do público. Nesse caso, tem-se uma forma de expressão irracional, com proeminência estética, simbólica, metafórica, em suma, poética.

No caso da sociedade do espetáculo, fica a questão de saber qual a efetividade de uma resistência que encontra no distúrbio sua estratégia de ação. Como Debord (1997) demonstrou, o espetáculo atua sobre as subjetividades para além dos limites da razão e da consciência, mirando, sobretudo, a dimensão inconsciente do imaginário e do desejo. Contrapor-se a essa tendência com meios inteiramente racionais dificilmente surtirá os efeitos desejados. Primeiro, porque o ser humano não é somente racional. E, segundo, porque a imaginação e a sensibilidade são mais propensas aos efeitos estéticos das artes.

Portanto, o paradigma estético da resistência artística e cultural que se vale da força criativa do distúrbio parece ser, senão o único, muitas vezes o mais apropriado para fazer frente ao poder de captura do desejo e das subjetividades na sociedade do espetáculo. Uma resistência antenada com o contemporâneo precisa compreender a política dos afetos, do desejo e do irracional, para, com essa apreensão, poder atuar de forma efetiva.

$\mathrm{Na}$ resistência ao espetáculo, a arte crítica reconhece o valor e a pertinência do imperativo estético do choque (CAE, apud McKenzie; Schneider, 2000:143). Em um mundo cujas sensibilidades são amortecidas e embotadas pela entropia de estímulos, a estética do distúrbio assume sua função como uma arte provocativa assumidamente impactante. Ao propor o distúrbio como tática da resistência artística, o choque torna-se um dos objetivos das intervenções do teatro recombinante e desempenha a mesma função que o distúrbio das ações de resistência eletrônica no ciberespaço. Face aos códigos e enclaves culturais, o artista e o ativista fazem o papel do hacker: furam barreiras ideacionais, subvertem lógicas, decodificam normalidades, descriptografam ideologias e assim por diante, sempre no interesse de liberar um elemento fechado em um dado sistema. 


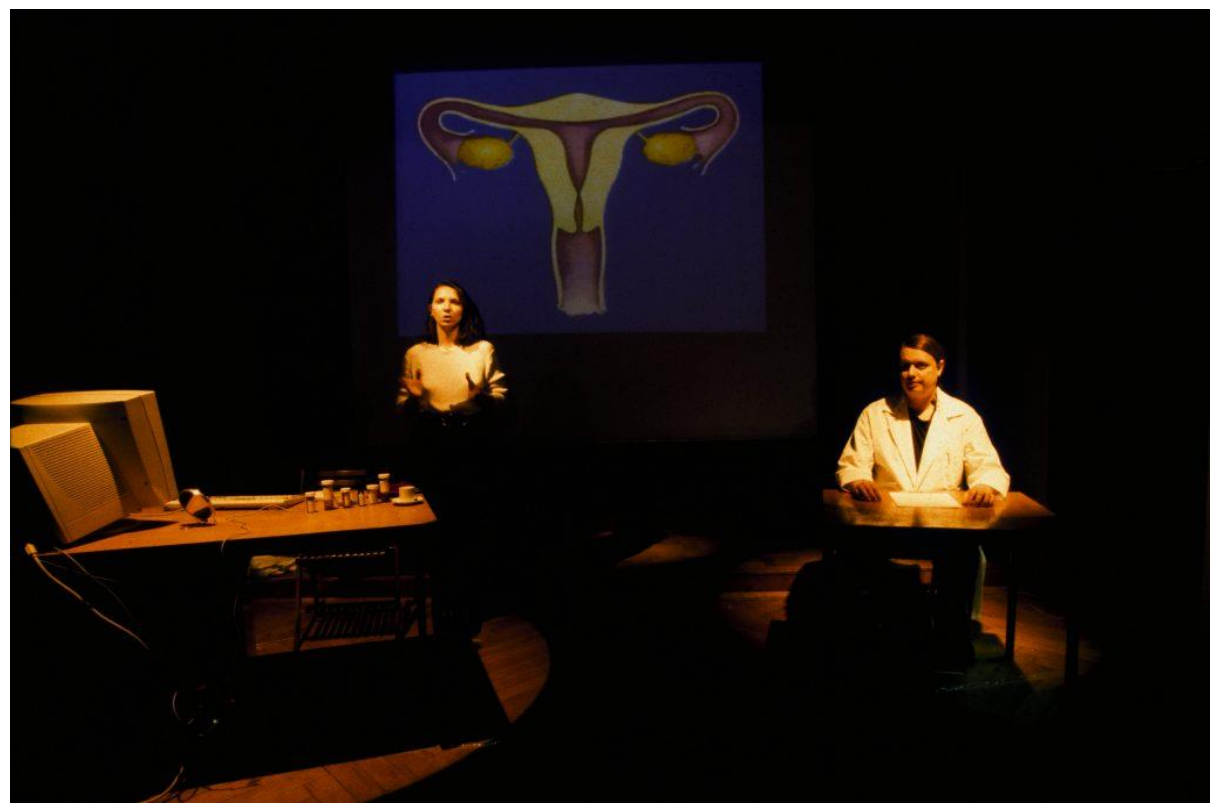

Imagem 7 - Flesh Machine, projeto e campanha do CAE, 1997-98. Dorian Burr e Steve Kurtz .

Por meio de suas produções, que podem ser artefatos ou performances, o CAE incide nos processos de subjetivação do público a fim de estimular rupturas e a ultrapassagem das fronteiras ideológicas de uma dada ordem simbólica, na tentativa de proporcionar a 219 emergência de focos autônomos de subjetivação: "O trabalho verdadeiramente perturbador (que para o CAE não significa 'chocante') de representação cultural ajudará cada indivíduo a progredir em direção a uma subjetividade mais completa - ele/ela será capaz de separar a si mesmo da objetividade da máquina" (CAE, 1996:39).

Esse tipo de intervenção cultural, por mais simples que seja, promove situações nas quais se opera uma subjetivação política, na acepção de Lazzarato (2014:21-22). Questões pouco refletidas, no mais das vezes sob a ótica interessada do marketing, são problematizadas para que o ceticismo desperte as condições do pensamento eclodir e recombinar os elementos semióticos, discursivos e epistemológicos sobre o assunto. Para que possa ocorrer, a subjetivação política deve necessariamente atravessar esses momentos nos quais as significações dominantes são suspensas. Essa é uma das principais funções políticas da subjetivação provocada pelas ações do CAE: trabalhar para a emergência de subjetividades autônomas, críticas, autoposicionadas.

Com razão, pode-se comparar a estética do distúrbio ao teatro da crueldade concebido por Antonin Artaud (1984:131-132), que fez da força vital um ímpeto transformador da cultura: "Do ponto de vista do espírito, a crueldade significa rigor, aplicação e decisão

\footnotetext{
${ }^{5}$ Imagem disponível em: http://critical-art.net/flesh-machine-1997-98/ [Consult. 31-07-2019].
} 
implacáveis, determinação irreversível, absoluta". O teatro artaudiano foi pensado para despertar o corpo e o espírito da passividade e da letargia, ao passo que a matriz performática do teatro recombinante agencia as forças da crueldade artística e instala uma "zona autônoma temporária" no campo social, no imaginário e na ordem simbólica, para usar a expressão de Hakim Bey (2001). ${ }^{6}$ O CAE (2012:134) explicita o fundamental de suas práticas intervencionistas:

Em nosso trabalho público, o CAE sempre tentou inventar maneiras de falar o indizível e revelar o invisível, seja a invisibilidade das margens, as alavancas ocultas de controle ou as ameaças e forças latentes que fundamentam a complacência normativa.

Lá onde impera a certeza, o distúrbio leva à dúvida, ao questionamento, ao ceticismo que varre as opiniões; onde reina a eficácia, o controle, a disciplina e a repressão, provoca o entrechoque das partículas imagéticas e comportamentais para promover um salto quântico, uma visão intempestiva sobre a vida, livre e aberta à criação. Trata-se, portanto, de um teatro micropolítico e tático que devasta ideologias sem recorrer à propaganda panfletária. É por isso uma arte micropolítica sagaz que se insinua, na perspectiva do CAE, nas mentes e nos corações dos participantes para injetar ânimo nas forças latentes da crítica e da revolta, no inconsciente individual e coletivo.

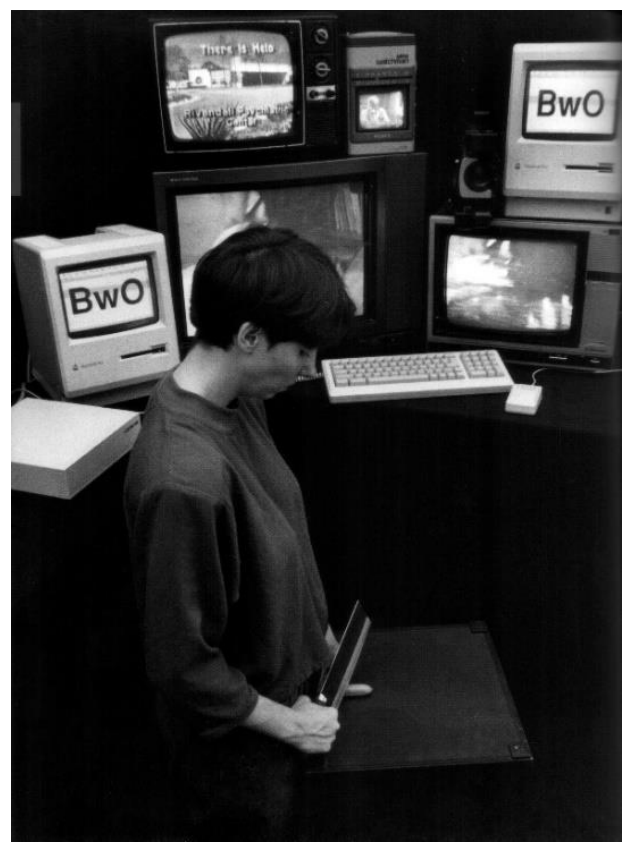

Imagem 8 - Dorian Burr em uma performance do CAE (2012:50)

\footnotetext{
${ }^{6}$ Para Hakim Bey, a expressão zona autônoma temporária é autoexplicativa. Trata-se de uma noção empregada pelo autor para tratar de zonas espaço-temporais criadas para o exercício da autonomia individual e coletiva, em termos de pensamento, imaginação, interação, relações, práticas comunitárias, artísticas e culturais em geral. "A TAZ ["temporary autonomous zone"] é uma espécie de rebelião que não confronta o Estado diretamente, uma operação de guerrilha que libera uma área (de terra, de tempo, de imaginação) e se dissolve para se re-fazer em outro lugar e outro momento, antes que o Estado possa esmagá-la” (Bey, 2001:17).
} 
A resistência ao poder nômade, tal como promulga o CAE, adquire, assim, um caráter destituinte, ao invés de constituinte. A lógica constituinte exige emparelhamento dialético com o poder, com o Estado. Foi sempre nessa direção que os revolucionários fizeram história. A lógica destituinte anseia outros meios. O coletivo Comitê Invisível (2017:94) trata do assunto: "Destituere significa, em latim: colocar em pé à parte, erigir isoladamente; abandonar; pôr de lado, deixar cair, suprimir; decepcionar, enganar". Em vez de combater frontalmente o poder e as instituições, a lógica destituinte deseja realizar o que se pretende sem recorrer a eles nem mesmo para destruí-los. Mais importante do que isso, trata-se de tornar as instituições inúteis por efeito das ações criativas, pela efetivação do que faz valer com o desejo. No contexto da resistência, implica desligamento, procura de vias alternativas que não passam pelas instituições estabelecidas.

Aqui se encontra a categoria de negação da negação como tática de que se vale a resistência cultural para abrir o campo de novas possibilidades na história, sem recorrer necessariamente a imagens preestabelecidas a serem impostas ao conjunto da sociedade. A recusa do proselitismo, ou a recusa de encarnar o modelo das vanguardas tradicionais que levavam a boa nova às massas, adquire seu sentido à medida que o CAE e as resistências culturais se permitem afirmar a vida em sua multiplicidade, garantindo, assim, a autonomia dos sujeitos históricos, individuais e coletivos. Não cabe aos coletivos contemporâneos guiar as massas rumo à instauração de um modelo de sociedade idealizado, senão que, mais apropriadamente, desfazer entraves, desestabilizar e desmantelar as redes de poder para abrir caminhos possíveis e virtuais, contribuindo com bifurcações criativas nas dimensões da cultura e de tudo o que comporta a vida cotidiana. Intervindo na ordem simbólica e nos regimes semióticos, a estética do distúrbio praticada pelo CAE tem, por isso, o propósito de desafiar o poder e provocar panes, falhas e avarias na funcionalidade reprodutiva do sistema. Assim, é possível colapsar as estruturas autoritárias e fazer crescer, por meio de uma bifurcação nos rumos históricos, nem que sejam vacúolos e vazios plenos de virtualidades, tanto nos processos subjetivos, epistemológicos e tecnológicos, quanto nas dimensões existenciais, no imaginário e nos modos de pensar, sentir, fazer e viver. Realmente, trata-se de uma aposta nas táticas do distúrbio para abrir brechas no entrecruzamento dos campos cultural, subjetivo, artístico e político. Mesmo o caos, outrora compreendido como ausência de ordem, propicia a criatividade, e a complexidade, seja em qual sistema for, promove novos arranjos e patamares de reorganização ${ }^{7}$.

\footnotetext{
7 "Nas ciências naturais, o ideal tradicional era alcançar a certeza associada a uma descrição determinista, tanto que até a mecânica quântica persegue esse ideal. Ao contrário, as noções de incerteza, de escolha e de risco
} 
Para manter o princípio da revolta aceso, sem que as potências sociais se percam na reencarnação do poder, o CAE faz valer sua tática na estética do distúrbio, aparentemente a melhor alternativa da potência destituinte dos poderes preestabelecidos de que lança mão. A arte crítica aposta suas fichas no jogo da resistência libertária - no campo macropolítico, face aos imperativos socioeconômicos dominantes, e no campo cultural, contra o espetáculo agenciando, para tanto, dispositivos e matrizes performáticas a fim de colapsar os circuitos do capitalismo por dentro com distúrbios estéticos e choques semióticos bem direcionados.

\section{Considerações finais}

Desde seu surgimento, o CAE aposta suas fichas no jogo pós-moderno em prol da autonomia e contra as tendências autoritárias na esfera da cultura, investindo sua criatividade na prática artística de resistência. Para fazer frente ao poder nômade do capitalismo, elabora uma crítica radical a dois dos maiores complexos tecnopolíticos da atualidade, a informática e a biotecnologia, sem recusar, no entanto, o papel das tecnologias na luta contra a opressão. Por isso, ao mesmo tempo, promove ricas pesquisas sobre as aplicações possíveis dos conhecimentos e das tecnologias em sentido contrário ao colocado em prática pelas indústrias e pelos Estados. Dessa forma, a fim de combater o controle e a vigilância, o CAE convoca a resistência para se apropriar das tecnologias com propósitos de libertação.

Nesse sentido, o CAE sintetiza a realização da arte engajada no contemporâneo, pois une arte, tecnologia e pesquisas acadêmicas fundindo-as em um todo coerente. Como dito neste artigo, o grupo é concretamente um coletivo de criação e estudos integrados (no sentido excepcional aqui empregado), pois agencia a imaginação e a criatividade típicas das artes com os estudos e as pesquisas pertinentes à tarefa da crítica, sempre engajado nas lutas concretas de seu tempo. O coletivo consegue, assim, orientar o potencial da revolta para o aspecto crítico e inventivo da resistência artística a fim de problematizar temáticas contemporâneas. Com esse objetivo, elabora teorias e linguagens argumentativas nos livros e manifestos, bem como linguagens imagéticas, simbólicas e não racionais direcionadas à dimensão dos sentidos, dos afetos e desejos. A estética do distúrbio favorece a criação de possibilidades nos campos do pensamento e da ação e, em última análise, abre o campo sociológico para a criação de universos incorpóreos capazes de se materializar nas subjetividades, nas relações, na vida cotidiana e na cultura. 
O legado do CAE deixa entrever, com singularidade, que a melhor forma de manter e sofisticar a capacidade de resistir é criar as condições de possibilidade da revolta se expressar na cultura compreendida como teatro de operações micropolíticas.

Ante as infinidades de matrizes interpretativas moldadas pelo espetáculo, todas investidas do caráter de verdade, cabe à estética do distúrbio minar o império das opiniões que obstruem a construção da autonomia nas suas dimensões individuais e coletivas. A provocação, a confusão e o distúrbio são meios de que se vale o teatro da resistência para desmontar as máquinas ideológicas e revelar potenciais escolhas não previstas pela grade interpretativa dominante do espetáculo.

Com o passar do tempo, algumas táticas empregadas pelo CAE e outros coletivos ativistas emergentes nas décadas recentes parecem ter sido assimiladas por organizações e grupos autoritários que têm interesse em desarticular os movimentos de resistência libertários e minar os direitos civis, individuais e coletivos. Campanhas de ódio, mensagens de intolerância, terrorismo cibernético, porém, nunca foram consideradas práticas de resistência. O ambiente cibercultural contemporâneo tem levado determinadas tendências a limites contraditórios e paradoxais. Os campos artístico e cultural não escapam a isso.

O certo é que tanto no caso do plágio utópico quanto na prática do teatro recombinante nota-se um teor crítico e político latente, afinal, era de se esperar que um coletivo de arte crítica elevasse a estética ao patamar da contestação. A relação da arte com a crítica tem uma história que se confunde com a da própria modernidade. Ao invés, porém, de relacionar unicamente a dimensão artística com a crítica, será melhor perguntar sobre os fundamentos da crítica que, na arte ativista, livre de quaisquer dogmatismos, encontra seu lugar de expressão por excelência como acontecimento estético. Afinal, se a arte é o espelho no qual uma época inteira pode se ver refletida, talvez tenha chegado o momento de perguntar o que aconteceu na história recente para que neocoletivismo pudesse existir. Tal pergunta lança o pensamento na busca pela contra-história da arte que encontra na revolta social seu impulso criador.

Foi porque a criatividade historicamente acumulada e estimulada no campo das artes extrapolou o campo artístico, dando vazão à inventividade humana e às aspirações do desejo por transformação, que as micropolíticas pós-68 tornaram-se criativas em um sentido mais proeminente a partir da década de 90 . Formas intervencionistas de se fazer arte, carregadas de teor social, fundiram-se com ações políticas inovadoras, por vias estéticas disruptivas, táticas e tecnológicas, dando consistência à tendência contemporânea do neocoletivismo em que estética e política tornam-se por vezes indiscerníveis em suas expressões semióticas e culturais. Performances, intervenções, mídia tática, guerrilha semiótica e forte apelo estético 
são algumas das formas do ativismo artístico empregadas pelo neocoletivismo. Todos esses elementos conferem o teor criativo às micropolíticas que vêm caracterizando a tendência atual.

\section{Referências}

AQUINO, Emiliano Fortaleza de (2006), Reificação e linguagem em Guy Debord. Fortaleza, EDUECE/Unifor.

ARTAUD, Antonin (1984), O teatro e seu duplo. São Paulo, Max Limonad.

BEY, Hakim (2001), TAZ: zona autônoma temporária. São Paulo, Conrad Editora do Brasil.

COMITÊ INVISÍVEL (2017), Motim e destituição agora. São Paulo, N-1 Edições.

CRITICAL ART ENSEMBLE (2001a), Distúrbio Eletrônico. São Paulo, Conrad Editora do Brasil. (2013), La Invasión Molecular: Biotecnologías: Teoria y Prácticas de Resistencia. Madrid, Enclave de Libros. . (1994), The Electronic Disturbance. New York, Autonomedia. . (1996), Eletronic Civil Disobedience and Other Unpopular Ideas. Brooklyn, Autonomedia. (1998), Flesh Machine: Cyborgs, Designer Babies, and New Eugenic Consciousness. Brooklyn, New York, Autonomedia.

. (2001b), Digital Resistance: Explorations in Tactical Media. Brooklyn, New York, 224 Autonomedia.

(2002), The Molecular Invasion: Contestational Biology. Brooklyn, New York,

Autonomedia.

. (2006), Marching Plague: Germ Warfare and Global Public Health. Brooklyn, New York, Autonomedia. . (2012), Disturbances. London, Four Corners Books.

. (2018), Aesthetics, Necropolitics, and Environmental Struggle. New York, Autonomedia.

DEBORD, Guy (1997), A sociedade do espetáculo. Rio de Janeiro, Contraponto.

DELEUZE, Gilles; GUATTARI, Félix (2004), Mil platôs: capitalismo e esquizofrenia, vol. 3. Rio de Janeiro, Ed.34.

FORTUNATO, Lucas (2019), Critical Art Ensemble: a máquina de guerra e os arsenais antropotécnicos da revolta. Tese (Doutorado em Ciências Sociais). Centro de Ciências Humanas, Letras e Artes, Universidade Federal do Rio Grande do Norte, Natal, $334 \mathrm{f}$.

. (2020), "Arte, Tecnologia e Resistência: Entrevista com Steve Kurtz, do Critical Art Ensemble", in Alex Galeno; Fagner França; Lucas Fortunato (org.), Rebelados da Cultura, volume 1: Revoltas e Antropolíticas. Natal, Caravela Selo Cultural, Edições Marginália, pp. 43-53.

FORTUNATO, Lucas; GALENO, Alex (2018), "Civilização, tecnologia e poder na modernidade líquida”. Revista Inter-Legere, v. 1, n. 23, p. 94-114 [Consult. 20-10-2020]. Disponível em https://periodicos.ufrn.br/interlegere/article/view/15878

FORTUNATO, Lucas; GONÇALVES FILHO, Edson; LORETO, Lisandro (2010), Machinapolis e a Caosmologia do Ser. Natal, EDUFRN.

GUATARRI, Félix (1977), Revolução molecular: pulsações políticas do desejo. São Paulo, Editora Brasiliense. 
HIMANEN, Pekka (2001), A ética dos hackers e o espírito da era da informação: a importância dos exploradores da era digital. Rio de Janeiro, Campus.

HORA Daniel de S. N. (2015), Teoria da arte hacker: estética, diferença e transgressão tecnológica. Tese (Doutorado em Arte). Universidade de Brasília, Brasília, 316 f.

INTERNACIONAL SITUACIONISTA (2002), Situacionista: teoria e prática da revolução. São Paulo, Conrad Editora do Brasil.

LAZZARATO, Maurizio (2006), As revoluções do capitalismo. Rio de Janeiro, Civilização Brasileira. . (2014), Signos, máquinas, subjetividades. São Paulo, Edições Sesc, N-1 Edições.

LUDD, Ned (org.) (2002), Urgências das ruas: Black Block, Reclaim The Streets e os Dias de Ação Global. São Paulo, Conrad Editora do Brasil.

MCKEE, Yates (2016), Strike Art!: contemporary art and the post-Occupy condition. Brooklyn, Verso.

MCKENZIE, Jon; SCHNEIDER, Rebecca (2000), "Tactical Media Practitioners: an interview". The Drama Review, 44, 4 [Consult. 28-08-2020]. Disponível em http://atc.berkeley.edu/201/readings/CAE2000Interview.pdf

MESQUITA, André Luiz (2008), Insurgências poéticas: arte ativista e ação coletiva (1990-2000). Dissertação (Mestrado em História Social). Faculdade de Filosofia, Letras e Ciências Humanas, São Paulo, 429 f.

MIRZOEFF, Nicholas (2004), "Anarchy in the ruins: dreaming the experimental university", in N. Thompson; G. Sholette (Eds.), The Interventionists: users' manual for creative disruption of everyday life. Massachusetts, MASS MoCA Publications, pp. 143-146.

MOORE, Alan (2002), General introduction to collectivity in modern art. [Consult. 20-10-2020]. Disponível em http://www.joaap.org/new3/moore.html

PRIGOGINE, Ilya (2002), As leis do caos. São Paulo, UNESP.

ROSAS, Ricardo (2003), Nome: coletivos, Senha: colaboração. Rizoma.net [Consult. 21-01-06]. Disponível em: http://www.rizoma.net/desenv/interna.php?id=170\&secao=intervencao (Referência extraída de Fernando do Nascimento Gonçalves (2007), Resistência nômade: arte, colaboração e novas formas de ativismo na Rede. Intercom - Sociedade Brasileira de Estudos Interdisciplinares da Comunicação, XXX Congresso Brasileiro de Ciências da Comunicação, Santos [Consult. 20-102020]. Disponível em http://www.intercom.org.br/papers/nacionais/2007/resumos/R0354-2.pdf . (2006), Notas sobre o coletivismo artístico no Brasil [Consult. 20-10-2020]. Disponível em https://desarquivo.org/sites/default/files/rosas_ricardo_notas.pdf

SCHNEIDER Michel (1990), Ladrões de palavras: ensaio sobre o plágio, a psicanálise e o pensamento. Campinas, Editora da Unicamp.

SHOLETTE, Gregory (2005), "Disciplining the Avant-Garde: The United States versus the Critical Art Ensemble". Circa, n. 112, pp. 50-59 [Consult. 26-10-2020]. Disponível em www.jstor.org/stable/25564316

STIMSON, Blake; SHOLETTE, Gregory (Ed.) (2007), Collectivism after modernism: the art of social imagination after 1945. London, University of Minessota Press. 
THOMPSON, Nato (Ed.) (2017), Living as Form: socially engaged art from 1991-2011. New York, Creative Time Books / London, The Mit Press.

Printing. (2015), Seeing Power: art and activism in the $21^{\text {st }}$ century. Brooklyn, Melville House - (2004), "Trespassing relevance", in Nato Thompson; Gregory Sholette (Ed.), The Interventionists: users' manual for creative disruption of everyday life. Massachusetts, MASS MoCA Publications, pp. 13-22.

THOMPSON, Nato; SHOLETTE, Gregory (Ed.) (2004), The Interventionists: users' manual for creative disruption of everyday life. Massachusetts, MASS MoCA Publications.

XAVIER, Luiz Gustavo Vidal (2006), "Os novos Citas do ciberespaço: Critical Art Ensemble: arte, crítica, tecnologia e ativismo político" [Consult. 20-10-2020]. Disponível em http://www.intercom.org.br/papers/nacionais/2006/resumos/R0987-1.pdf

WOOD, Paul (2002), Arte conceitual. São Paulo, Cosac \& Naify. 


\begin{abstract}
The article handles the Critical Art Ensemble (CAE), a North American collective composed of activist artists who since 1990 have been promoting relations among art, intervention, and critical theory. We present the place of CAE in the socio-historical context, which we named as new collectivism, a sociological phenomenon emerging in the last decades. We adopted a micropolitical perspective and sociology and history theories to support the study, as well as contemporary art criticism. It is a case study based on bibliographic and documentary research. The analyzed data made it possible to understand the collective's trajectory, its way of organizing, creating, and acting in the cultural sphere. The research results present CAE as an example of new collectivism, a trend characterized by interventionist performing, where esthétic and politics sometimes become indiscernible in their semiotic and cultural expressions.
\end{abstract}

Keywords: Critical art ensemble; utopian plagiarism; recombinant theater; aesthetics of the disturbance; new collectivism.

\title{
Resumen
}

Este artículo tiene como objetivo abordar el Critical Art Ensemble (CAE), un colectivo de artistas y activistas estadounidenses que, desde la década de 1990, ha estado promoviendo conexiones creativas entre el arte, la intervención y la teoría crítica. Con una perspectiva micropolítica y soportes teóricos de la sociología, la historia y la crítica del arte contemporáneo, presentamos el lugar del CAE en el contexto socio-histórico de lo que llamamos neocolectivismo, fenómeno sociológico emergente en las últimas décadas, y algunas de sus formas de expresión. Es un estudio de caso basado en una investigación bibliográfica y documental. Los datos analizados permiten comprender la trayectoria del colectivo, su forma de organizarse, crear y actuar en el ámbito de la cultura. Los resultados de la investigación demuestran que el CAE es un caso ejemplar de neocolectivismo, una corriente caracterizada por formas de acción intervencionista en las que la estética y la política son generalmente indiscernibles en sus expresiones semióticas y culturales.

Palabras clave: Critical art ensemble; plagio utópico; teatro recombinante; estética de la perturbación; neocolectivismo. 